\title{
LATE HOLOCENE CLOSURE OF A BARRIER BEACH IN SEPETIBA BAY AND ITS ENVIRONMENTAL IMPACT (RIO DE JANEIRO, BRAZIL)
}

\author{
Anita Fernandes Souza Pinto ${ }^{1}$, Maria Virgínia Alves Martins ${ }^{1,2 *}$, Maria Clara Machado da Fonseca ${ }^{1}$, Egberto \\ PEREIRA $^{3}$, DENISE LARA TERroso ${ }^{2}$, FERNANdo ROCHA ${ }^{2}$ AND MARIA ANTONIETA dA CONCEIÇÃo RODRIGUES ${ }^{1}$
}

1 Laboratório de Micropaleontologia, Universidade do Estado do Rio de Janeiro - UERJ, Faculdade de Geologia, Departamento de Paleontologia e Estratigrafia. Av. São Francisco Xavier, 524, sala 4037F, Maracanã. 20550-013 Rio de Janeiro, RJ, Brazil. anitafspinto@gmail.com, virginia.martins@ua.pt, geomariaclara@gmail.com, tutucauerj@gmail.com

2 Universidade de Aveiro, Departamento de Geociências, GeoBioTec, Campus de Santiago, 3810-193, Aveiro, Portugal. tavares.rocha@ua.pt, laraterroso@ua.pt

3 Universidade do Estado do Rio de Janeiro - UERJ, Faculdade de Geologia, Departamento de Paleontologia e Estratigrafia. Av. São Francisco Xavier, 524, sala 2020A, Maracanã. 20550-013 Rio de Janeiro, RJ, Brazil. egbertogeologia@gmail.com

*Corresponding AUthor, virginia.martins@ua.pt

Received on 19 February 2017

Received in revised form on 24 March 2017

Accepted on 27 March 2017

Editor: Alberto Garcia de Figueiredo Jr, Universidade Federal Fluminense, Rio de Janeiro, Brazil
SCREENED BY

$\checkmark$ iThenticate
Citation:

Pinto, A.F.S., Martins, M.V.A., Fonseca, M.C.M., Pereira, E., Terroso, D.L., Rocha, F., Rodrigues, M.A.C., 2017. Late Holocene closure of a barrier beach in Sepetiba Bay and its environmental impact (Rio de Janeiro, Brazil). Journal of Sedimentary Environments, 2 (1): 65-80.

\section{Abstract}

Core T4 (with $286 \mathrm{~cm}$ long) collected in the inner part of Sepetiba Bay is a record of late Holocene evolution of this ecosystem. This core was described and sampled every $2 \mathrm{~cm}$. Samples were submitted to textural, geochemical and foraminifera analyses. Two radiocarbon dates were obtained. Estimated ages indicate that core $\mathrm{T} 4$ represents the last $\approx 4,000$ years calibrated before present (yrs cal BP).

Results of this core suggest that coarse sediments, recorded in the period between $\approx 4,000-3,400$ yrs cal BP, were probably associated with high hydrodynamic conditions in the study area. These sediments should be deposited at an incipient phase of the Marambaia Beach Barrier evolution. The development of this sand barrier protected the inner region of Sepetiba Bay from the action of strong waves and active coastal currents and favored its confinement. This area of Sepetiba Bay became a low energy system, which favored the deposition of fine-grained sediments rich in organic matter content. Organic matter enrichment increased especially in the upper core section. Foraminifera assemblages and carbonates content indicate that the studied region also should have been affected in the last $\approx 3,400$ yrs cal BP by changes in the water depth column.

The results obtained in the core T4 show that the confinement and eutrophication process of the internal zone of Sepetiba Bay has been occurring since $\approx 3,400$ yrs cal BP and should have been caused by factors such as geomorphological, climatic changes and human activities, which influenced the its hydrodynamics and sedimentary dynamics.

Keywords: Foraminifera. Total organic matter enrichment. Paleoenvironmental Evolution. Coastal area. Tropical Climate. 


\section{Introduction}

The use of fossils, mainly foraminifera, has been greatly applied in studies of paleoenvironmental evolution through the Quaternary, in Brazil (e.g. Costa et al., 2006; Petró et al., 2016). Those works were based on the paleoecology of benthic and/or planktonic species and/or isotopic data in the tests of these microorganisms. Foraminifera represent a group of interest in paleoenvironmental research due to their: sensitivity to environmental variations, reflecting ecological conditions of the region where they live or lived; small size, high abundance and diversity in most of marine and transitional systems and easy processing and storage (Schönfeld et al., 2012).

Several studies on sea level oscillation were performed in Sepetiba Bay (Brazil) mainly in the Holocene, such as those of Figueiredo-Jr. et al. (1989), Laut et al. (2006), Roncarati and Carelli (2012), Friederichs et al. (2013) and Borges and Nittrouer (2016 a, b).

Among the studies that used foraminifera assemblages aiming to investigate the paleoenvironments related to sea level changes in Sepetiba Bay (Brazil), there are, for instance, the works of Laut et al. (2006), Laut and Rodrigues (2011) and Pinto et al. (2016). The studies of Fonseca et al. (2007) and Bruno (2013), for example, based on foraminifera and performed on coastal systems of Rio de Janeiro State, in Guanabara Bay and Saquarema Lagoon, respectively, suggested the occurrence of a Holocene sea level maximum at about 5,000 BP.

\subsection{The main goals}

This work intends to be a contribution to the study of the late Holocene evolution of Sepetiba Bay, Rio de Janeiro State (Brazil), using sedimentary and foraminifera data obtained along the core T4, collected in the inner zone of this coastal system. The age model of this core was based on two radiocarbon data and the results were compared with that obtained by Pinto et al. (2016) in core T1 collected in the nearby Guaratiba Coastal Plain (mangrove).

\section{Study area}

Sepetiba Bay is located in the southwest region of Rio de Janeiro State (Brazil). With an area of $305 \mathrm{~km}^{2}$, it has an ellipsoidal contour and is a semi-confined transitional system, protected from the energy of the open ocean by a long barriers beach known as Marambaia Barrier (Fig. 1). The region is under a hot-humid tropical climate, with mean annual precipitation reaching 2,500 $\mathrm{mm}$ (Lacerda et al.,
2001). The northeastern sector of the bay receives freshwater from several rivers, mainly the Guandú River, with a drainage area of $1,385 \mathrm{~km}^{2}$ and a discharge of $19.1 \mathrm{~m}^{3} / \mathrm{s}$ (Tubbs Filho et al., 2012). The Guandú River, with $48 \mathrm{~km}$ long, receives the contribution of Santana and Ribeirão das Lages rivers (Oliveira et al., 2011). Much of its water comes from the Paraíba do Sul River, through a transposition that occurs in the municipality of Barra do Piraí.

In the past, the region was subject to constant floods due to its flat topography, then the rivers that flow into Sepetiba Bay have been rectified, dredged, channeled, and joined by dikes, since the $17^{\text {th }}$ century (Tubbs Filho et al., 2012). Therefore, nowadays most of the rivers present their low courses much modified in relation to what they were originally (Tubbs Filho et al., 2012).

Sepetiba Bay presents predominantly marine characteristics, at least in the outermost sector, but its inner zone behaves like a multi-estuary with depths of about $10 \mathrm{~m}$ on its most part and more than 20 meters in the main channel. Thus, the bay is a water body of saline and brackish water that communicates with the Atlantic Ocean through two passages: in the west part, between a group of islands and the tip of the Marambaia Barrier Island; and in the eastern portion, by a channel that flows into the Barra de Guaratiba inlet. In general, the salinity varies between 22 and 32 and it decreases from the outer sector to the inner region which has salinities of less than 30 (Araújo and Santos, 1999).

Water circulation on Sepetiba Bay is clockwise, mainly ruled by tidal forces (DHN, 1986). Tides have amplitudes less than $2.0 \mathrm{~m}$ (Villena et al., 2012). The pattern of surface currents follows the bottom topography, creating a preferential accumulation area of sediments along the northern coast $\mathrm{f}$ this bay (Suguio et al., 1979).

Sepetiba Bay sediments include sand, silt and clay. In some stretches the sediments are sandy, mainly in areas near the connection to sea and along the Marambaia Barrier Island; close to the mouth of the São Francisco Channel where exists a small delta related to river processes (Roncarati and Barrocas, 2012; Villena et al., 2012; Borges and Nittrouer, 2016 a, b). However, mud occupies $70 \%$ of the bay and is the dominant sediments granulometry.

The inner northern region of Sepetiba Bay is bordered by mangrove forests and receives polluted waters from rivers and channels that drain several towns and industries. The rivers are polluted with domestic and industrial untreated effluents as well as agricultural waste (Oliveira et al., 2011). The industrial activity of this region accounts for the release 
of several potentially toxic substances in the tributaries that flow into Sepetiba Bay, especially trace elements, which, due to the chemical reactions with the organic matter and the movement of tides, are accumulated mainly in the inner zone of the bay (Lacerda et al., 1987, 2001; Rezende et al., 1991; Dornelles, 1998; Calil et al., 2006).

The water quality in Sepetiba Bay is affected by effluents from several small towns and villages that do not have sewage treatment plants (Copeland et al., 2003). The incrising input of nutrients in the bay resulted in the eutrophication of its coastal waters (Tenenbaum et al., 2004). Due to its natural characteristics, the region has been traditionally used for fishing and tourism, but the pollution generated by industrial and urban activities is causing alarming rates of contamination (Ferreira and Moreira, 2015). In order to allow the expansion of the Sepetiba Port and suitability for receiving larger and faster vessels, the access channel and the basin require dredging to deepen the navigable area. These activities remobilize polluted bottom sediments and cause problems to the biota (Calil et al., 2004).

The introduction of exotic species into different ecosystems, by means of the ballast water of ships and the hull and moorings inlay, is now considered one of the four greatest pressures to the world's oceans (International Joint Commission, 2001). In contrast to other forms of pollution, which are reversed by mitigating measures, the import and export of invasive species through ballast water are considered drastically irreversible (Kolar and Lodge, 2001).

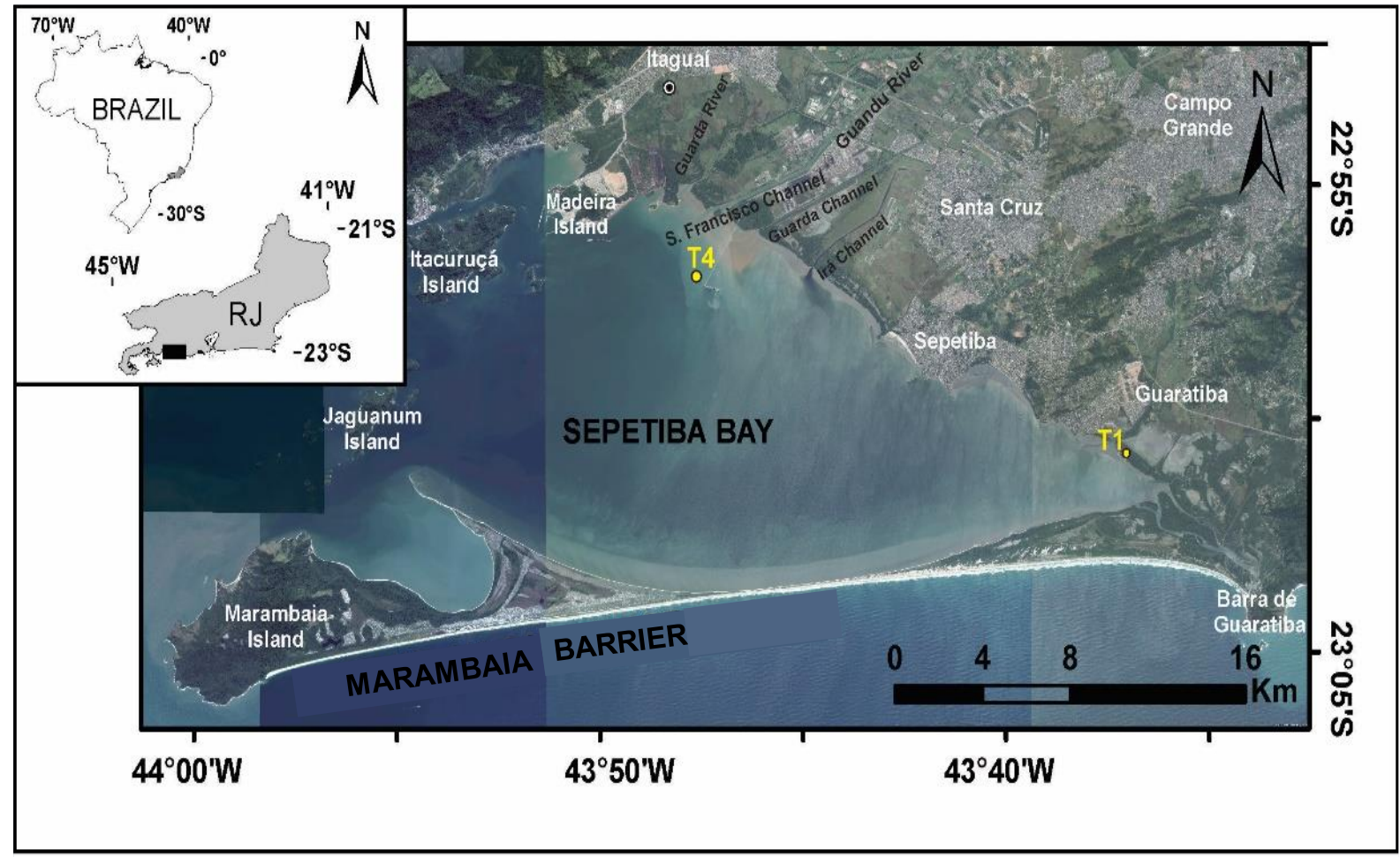

Fig. 1. Location of the core T4 analyzed in this work, as well core T1 studied by Pinto et al. (2016). Modified from Google Earth (datum WGS84). Legend: RJ - Rio de Janeiro, Brazil.

\section{Material and methods}

\subsection{Core sampling}

Core T4 (286 cm of core length) was collected in the inner part of Sepetiba Bay (latitude $22^{\circ} 57^{\prime} \mathrm{S}$, longitude $43^{\circ}$ $47^{\prime} \mathrm{W}$ and $3.0 \mathrm{~m}$ of water depth; Fig. 1). This core was collected in July 2015, by a team of divers from Husky Duck
Enterprise of Rio de Janeiro (Brazil). Core T4 was collected in PVC liners by means of percussion. It was kept refrigerated until the beginning of the laboratory work. The lithology of core T4 was described. It was sampled at each 2 $\mathrm{cm}$. Samples collected at each $2 \mathrm{~cm}$ were weighed and dried in an oven at $50{ }^{\circ} \mathrm{C}$. After drying, the samples were split for sediment grain size, benthic foraminifera and geochemical analyses. 


\subsection{Textural and geochemical analyzes}

A portion of each dry sample was weighed (initial weight). The samples were then washed with distilled water in a 63 $\mu \mathrm{m}$ sieve to separate the coarse-grained sediments (> $63 \mu \mathrm{m})$ from the fine fractions $(<63 \mu \mathrm{m})$. Both sedimentary fractions were collected in beakers and dried in an oven at $50{ }^{\circ} \mathrm{C}$.

After drying, the sand plus gravel fractions and the fine fractions were weighed and stored in plastic bags. The sedimentary fraction $>63 \mu \mathrm{m}$ of each sample was dry sieved $(125 \mu \mathrm{m}, 250 \mu \mathrm{m}, 500 \mu \mathrm{m}, 1000 \mu \mathrm{m}$ and $2000 \mu \mathrm{m})$. The weight and percentage of each granulometric fraction were determined. The textural classification of sediments was based on Folk and Ward (1957).

A portion of about $250 \mathrm{mg}$ of sediment of each sample was submitted to total organic carbon (TOC) and total sulfur (S) analysis in the Laboratory of Chemostratigrahy and Organic Geochemistry (LGQM-UERJ), with the LECO SC632 analyzer. The percentages of TOC, S and carbonates contents and insoluble residue were determined.

\subsection{Radiocarbon dating}

Two results of radiocarbon dating were obtained on organic matter and mollusk shells recovered from $112 \mathrm{~cm}$ and $212 \mathrm{~cm}$ layers, respectively. The radiocarbon analyses were performed in the Beta Analytic Laboratory (Miami, Florida). For the level $112 \mathrm{~cm}$, only the "Conventional Radiocarbon Age" is reported. The age obtained for the level $212 \mathrm{~cm}$ was calibrated using Marine 13 database (Reimer et al., 2013) and the delta R $32 \pm 44$ (Alves et al., 2015). For this level, a 2-sigma calibrated age before present (BP) was used. The core age model was estimated by linear interpolation of radiocarbon data.

\subsection{Foraminifera}

Sediment samples were spit in aliquots of $10 \mathrm{ml}$ of sediment. The sediment fraction $63-500 \mu \mathrm{m}$ was separated by wet sieving. After washing, the samples were dried in an oven at $50{ }^{\circ} \mathrm{C}$. Foraminiferal tests were separated from the sediment, identified and counted under a binocular microscope (maximum magnification 480X) and fixed in microslides (Uehara et al., 2007). All the specimens found were identified and counted in each sample. Foraminifera density (the number of specimens per each species per $10 \mathrm{ml}$ of sediment) and the species richness the number of species in the same volume of sediment were determined.

The species identification was based on several references, such as Loeblich and Tappan (1988), Debenay et al. (1998), Semensatto-Jr. and Dias-Brito (2004), Raposo et
RESEARCH PAPER

al. (2016) and Belart et al. (2017). The species nomenclature was updated following the World Foraminifera Database (Hayward et al., 2017).

\subsection{Statistical analysis}

Abiotic and biotic data, including foraminifera density, species richness and the main species (the most abundant and with occurrences in more than 5 layers along the core T4) were statistically analyzed after to be transformed by log $(x+1)$ and submitted to Principal Component Analysis. Pearson correlations between the variables were also determined. Correlations are significant at $p<0.05$. Statistical analysis was carried out with the Statistica ${ }^{\circledR} 12$ software.

\section{Results}

\subsection{Radiocarbon results}

Radiocarbon results provided the age of $60 \mathrm{yrs}$ cal BP (1955 AD) for the layer of $112 \mathrm{~cm}$. Radiocarbon dating for the layer of $212 \mathrm{~cm}$ resulted in: measured radiocarbon age of $2310 \pm 30 \mathrm{BP}$; conventional radiocarbon age of $2350 \pm 30$ $\mathrm{BP}$ and; a calibrated age (2-sigma) of 2,365 to 2,335 years calibrated before present (yrs cal BP). The estimated age for the basis of the core T4, based on this radiocarbon result, is $\approx 4,000 \mathrm{yrs}$ cal BP. These radiocarbon data indicate that the mean accumulation rate of sediment in the last $\approx 3,400$ yrs cal BP should have been $\approx 0.09 \mathrm{~cm} /$ year and in the last $\approx 100$ years, $\approx 1 \mathrm{~cm} /$ year.

\subsection{Core lithology and textural data}

Figure 2 displays a schematic representation of the core T4 stratigraphic column ( $286 \mathrm{~cm}$ long), showing that it is composed essentially by mud $(<63 \mu \mathrm{m})$ with intercalations of sandy sediments. Fine fraction $(<63 \mu \mathrm{m})$ is predominant (mean $=96.92 \%)$ along the core T4 . Between the core base $(286 \mathrm{~cm})$ and the level of $130 \mathrm{~cm}$, the increase of the sand fraction is observed such as at the layers: $286-279 \mathrm{~cm}, 243$ $\mathrm{cm}, 170-160 \mathrm{~cm}$ and $142-128 \mathrm{~cm}$ (Fig. 3). The section between 286-279 cm contains relatively high sand fraction content, which reaches $50 \%$.

The observation at the binocular microscope reveals that the sand fraction $(<63 \mu \mathrm{m})$ is basically composed of quartz and mica. Bioclasts, represented by complete and fragmented mollusk shells, were identified mainly in the lower half of the core. The most common species of mollusks was the gastropod Bulla striata. Rusted vegetable fragments were also recorded at the base of the core up to $263 \mathrm{~cm}$. 


\subsection{Geochemical results}

The results of total organic carbon (TOC; \%), total sulfur $(\mathrm{S} ; \%), \mathrm{C} / \mathrm{S}$ ratio and calcium carbonate $\left(\mathrm{CaCO}_{3} ; \%\right)$ are shown in Appendix 1 and Fig. 3. TOC values were generally high $($ mean $=1.85 \%$ ), ranging from $0.97 \%$ (in $283 \mathrm{~cm}$ ) to $2.90 \%$ (in $114 \mathrm{~cm}$ ). A tendency of increasing of TOC values from the base to the core top $\left(\mathrm{R}^{2}=0.58\right)$ was observed. The lowest TOC values were recorded at the core base between $286-168 \mathrm{~cm}$ (0.97-1.49\%). The highest TOC contents occurred in the section 126-72 cm (2.04-2.90\%) (Fig. 3).

The mean value of sulfur content was $0.83 \%$. The lowest values of this variable were recorded in the sections between $285-237 \mathrm{~cm}$ and $70-47 \mathrm{~cm}$, and the highest values were observed between 164-138 cm.

The lowest values of both S and TOC contents occur in core layers with relatively coarse sediments. The mean value of the $\mathrm{C} / \mathrm{S}$ ratio in core $\mathrm{T} 4$ was 2.35 .

Relatively high $\mathrm{C} / \mathrm{S}$ values were recorded in the sections 286-241 cm and between $124 \mathrm{~cm}$ and the core top. The C/S ratio values were lowest in the sediments of the core midsection $(240-130 \mathrm{~cm})$.

Concentrations of $\mathrm{CaCO}_{3}($ mean $=16.11 \%)$ ranged from $5.56 \%(193 \mathrm{~cm})$ to $23.81 \%(9 \mathrm{~cm})$. The lowest $\mathrm{CaCO}_{3}$ values occurred between $237-180 \mathrm{~cm}$ and $106-75 \mathrm{~cm}$, whereas the highest values were observed in the upper $15 \mathrm{~cm}$ of the core.

\subsection{Benthic foraminifera}

Foraminifera density values (number of specimens/10 $\mathrm{ml}$ ) ranged from 0 to 408 specimens $/ 10 \mathrm{ml}$. Foraminifera density in most part of core T4 is quite low. In the base (286$250 \mathrm{~cm})$ and top $(130-0 \mathrm{~cm})$ sections of this core, foraminifera are rare or absent.

The largest abundance of foraminifera tests was observed between $239-130 \mathrm{~cm}$, along with mollusk shells and valves of ostracods. The highest foraminifera densities were recorded in $229 \mathrm{~cm}$ (408 specimens $/ 10 \mathrm{ml}), 223 \mathrm{~cm}(396$ specimens $/ 10 \mathrm{ml}$ ) and $130 \mathrm{~cm}(266$ specimens $/ 10 \mathrm{ml})$.

Only species with carbonated tests were found in core T4 (Appendix 2 and Fig. 4). Thirty-eight species of benthic foraminifera were identified (Table 1). The species richness (SR) ranged from 0 to 16 species $/ 10 \mathrm{ml}$ per sample. The section between $237-221 \mathrm{~cm}$ presented the highest values of SR, coinciding with the highest densities of the sample. However, in the upper $45 \mathrm{~cm}$ of the core T4, high values of SR were registered along with reduced densities.

The most abundant species were Cribroelphidium excavatum, Elphidium gunteri, Ammonia tepida, Ammonia parkinsoniana and Buliminella elegantissima (Fig. 4; Appendix 2). Among these species, C. excavatum and A. tepida occurred in all the intervals in which foraminifera were found. Cribroelphidium excavatum was the most abundant species and reached slightly higher densities than $A$. tepida, near the core base.

In the core top, $A$. tepida was the most abundant species. In this section, discrete increases of $B$. elegantissima abundance were also recorded. The highest density of this species occurred between 241-200 cm. Quinqueloculina seminula was found between $231-219 \mathrm{~cm}$, in a section with higher foraminiferal density and species richness. Between $155-130 \mathrm{~cm}$, peaks of abundance of $A$. parkinsoniana, $A$. tepida and E. gunteri were recorded.

\subsection{Statistical results}

Figure 5 shows the results of the two first factors of the PCA, which explain most part of data variability. The explained variability of factor 1 and factor 2 are $0.55 \%$ and $0.33 \%$, respectively. Four groups of variables can be considered in this PCA: Group 1, composed of $\mathrm{CaCO}_{3}$; Group 2, including all the main species/taxa, as well as FD and SR; Group 3, containing sand fractions and the C/S values; and Group 4, encompassing fine fraction, TOC and $S$ content.

Pearson correlations among the analyzed variables (Appendix 3) evidence that there are significant positive correlations among: i) sand fractions and total sand fraction content; ii) fine fraction, TOC and S contents; iii) S, FD and SR; and iv) most of the species of foraminifera with each other.

The following variables have negative significant correlations: i) fine fraction, sand fractions and total sand fraction content; ii) TOC and FD; and iii) $\mathrm{CaCO}_{3}, \mathrm{FD}, \mathrm{SR}$ and most of foraminifera species. Some species have significant negative correlation with TOC such as $A$. parkinsoniana, A. rolshauseni, C. excavatum, C. selseyense, E. gunteri and E. williamsoni.

\section{Discussion}

\subsection{Sedimentological data}

Most part of core T4 is composed mainly of muddy sediments, in which fragmented mollusk shells and ostracod valves occur, in addition to layers with great abundance of foraminifera and sand fraction. Increases in percentage of sand fraction were observed in several sections $(286-279 \mathrm{~cm}$, $170-160 \mathrm{~cm}$ and $145-128 \mathrm{~cm}$ ).

Sedimentary TOC and S contents are relatively high throughout the core $\mathrm{T} 4$, which indicates that the supply, accumulation and preservation of organic matter were high 
in the study area, in the last $\approx 4,000$ yrs BP. The percentage of TOC decreased in the sections with relatively high sand fraction content but increased in fine-grained sediments. This relationship between TOC contents and sediment granulometry (evidenced by both the PCA and Pearson correlations; Fig. 5 and Appendix 3) is probably related to changes of the hydrodynamism in the study area. The deposition of coarse-grained sediments with relatively low TOC content should be related to strong hydrodynamical conditions. On the contrary, the weak hydrodynamism may have favored the deposition of fine-grained sediments and organic matter.

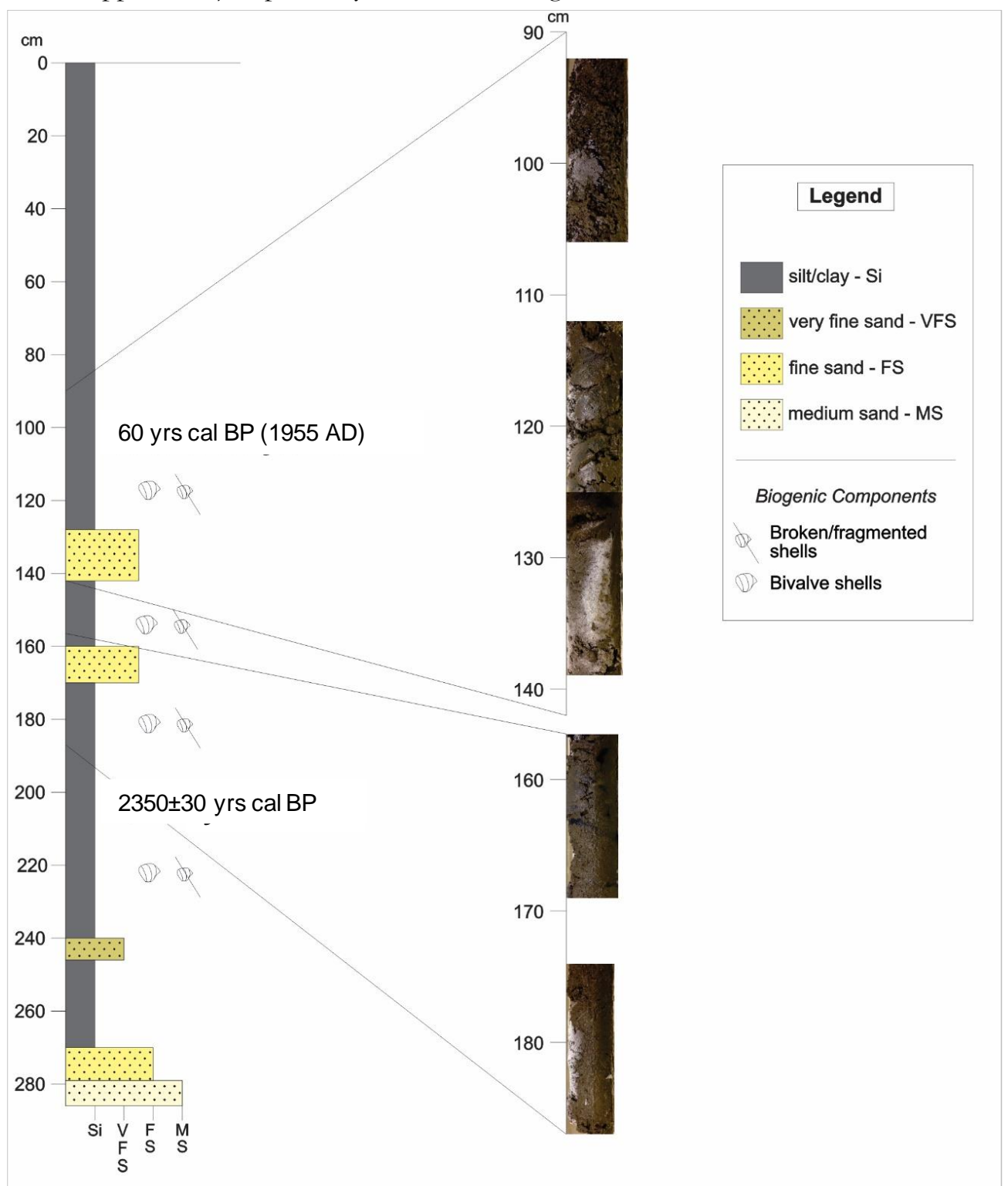

Fig. 2. Macroscopic description of core T4. Radiocarbon results are presented. Photographs of some sections of core T4 are shown on the right side, evidencing its predominantly muddy composition. Below a particle size scale is presented. 


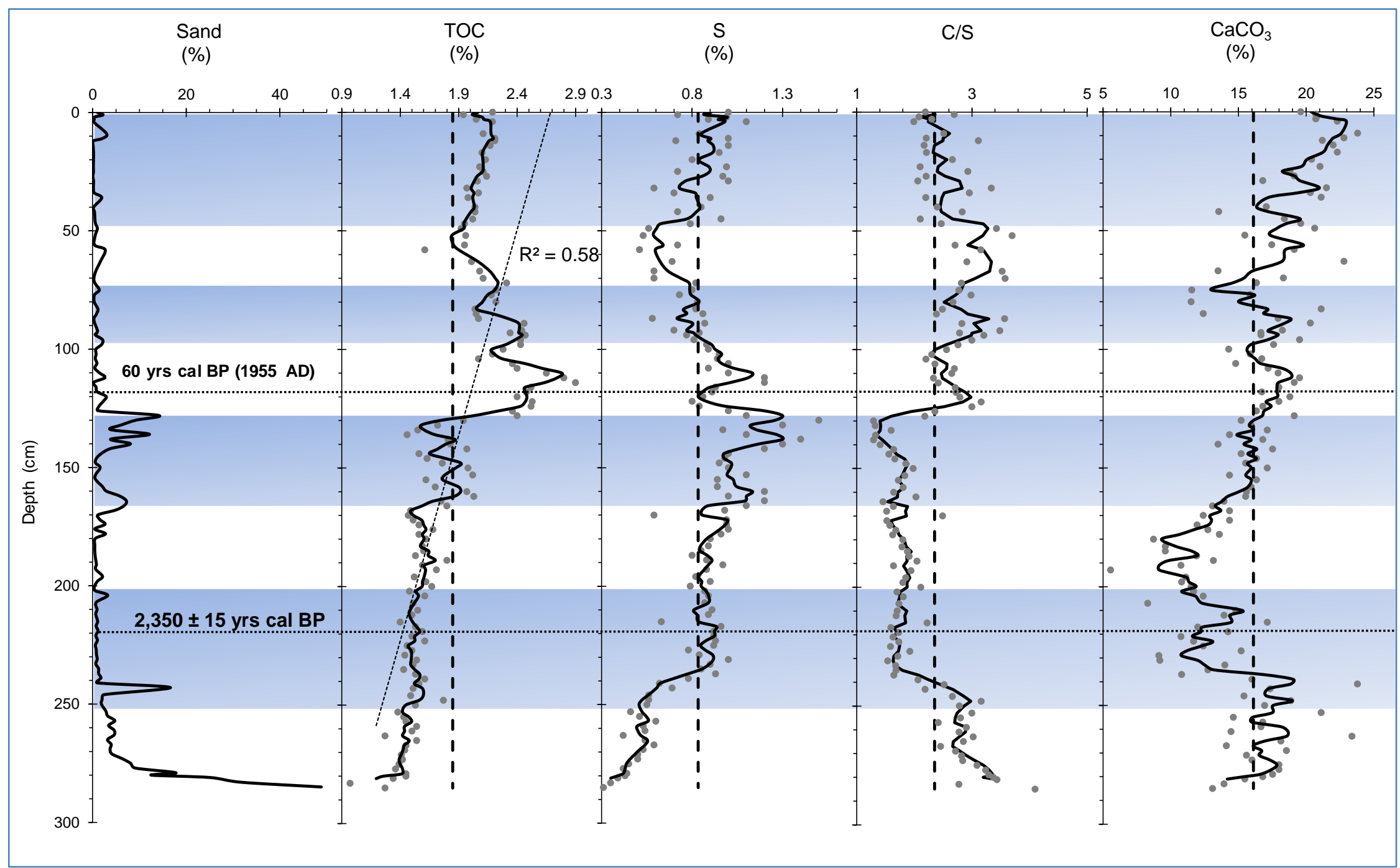

Fig. 3. Depth plot of the percentage of sand fraction (\%), TOC (\%), S (sulfur; \%), C/S ratio and $\mathrm{CaCO}_{3}$ (carbonate; \%) along the core T4. For the percentages of sand, density and specific richness, the data are represented by solid black lines; for TOC, $\mathrm{S}, \mathrm{C} / \mathrm{S}$ ratio and $\mathrm{CaCO}_{3}$, values are represented by dots, mean values by dotted black lines, and moving average by solid black lines. The blue bands indicate sections with higher foraminifera densities and species richness and the most significant variations of the sedimentological parameters. The obtained radiocarbon ages are also indicated. The trend line and respective $\mathrm{R}^{2}$ value was presented for TOC depth plot. 
Sulfur also has significant positive correlation with fine fraction and negative one with sandy fractions (namely coarse sand, medium sand, fine sand, and very fine sand; Fig. 5; Appendix 3). The highest $\mathrm{S}$ contents were recorded in the section $240-135 \mathrm{~cm}$, where C/S ratio displays the lowest values $(<3)$, indicative of low oxic conditions in the sediment (Stein, 1991; Borrego et al., 1998). C/S ratio reached highest values at the core base $(280-240 \mathrm{~cm})$ and in the core top (upper $120 \mathrm{~cm}$ ), indicating the presence of more oxic sediments in these sections (Morse and Berner, 2000). The highest values of C/S ratio at the core base $(280-240 \mathrm{~cm})$ are associated with sandy sediments, deposited probably under stronger hydrodynamic conditions than at the core top. In the upper $100 \mathrm{~cm}$, the sediments were quite fluidized, with relatively high-water content. Therefore, in spite of the high TOC contents recorded in this section, the poor compaction of the sediments should have facilitated the oxygenation.

Relatively high carbonate contents were found between $286-279 \mathrm{~cm}(\approx 4,000-3,200 \mathrm{yrs} \mathrm{cal} \mathrm{BP})$ and in the upper 130 $\mathrm{cm}$, in sections where foraminifera tests are rare or absent. This relationship is also evidenced by the PCA (Fig. 5) and by Pearson correlations (Appendix 3), which evidence that $\mathrm{CaCO}_{3}$ content is negatively correlated with foraminifera density, species richness and most part of the main species abundance. The rise of $\mathrm{CaCO}_{3}$ contents is not coincident with the increase of mollusk shells and ostracod valves. These features suggest that, in the mentioned sections (286$279 \mathrm{~cm}$ and in the upper $130 \mathrm{~cm}), \mathrm{CaCO}_{3}$ contents should be linked mostly with chemical precipitation favored by evaporitic processes in a shallow water column.

Therefore, the lower and upper core sections (286-279 $\mathrm{cm}$ and $130-0 \mathrm{~cm}$ ) characterized by low abundance of foraminifera and relatively high $\mathrm{CaCO}_{3}$ contents should have corresponded to phases of depth reduction, in the area where core T4 was collected. The shallow water column should have been disadvantageous for the benthic faunas and, in counterpart, gave rise to chemical precipitation (Rouchy et al., 2001). High $\mathrm{CaCO}_{3}$ contents were also found in core T1 at Magaratiba coastal plain in the last $\approx 300 \mathrm{yrs} \mathrm{cal}$ BP (upper $150 \mathrm{~cm}$ of that core). These values were associated by Pinto et al. (2016) with evaporitic series in the salt flats in the site of core T1 (the current apicum and mangrove environment).

\subsection{Composition of benthic foraminifera assemblages}

Foraminifera are rare or absent in basal $(286-250 \mathrm{~cm})$ and top $(130-0 \mathrm{~cm})$ sections of core $\mathrm{T} 4$, which may indicate the occurrence of unfavorable conditions for the development of large populations of these organisms, as refereed.
However, episodes with relatively high densities of benthic foraminifera were identified, notably between $\approx 3,000-2,000 \mathrm{yrs}$ cal BP $(241-200 \mathrm{~cm}$ and $196-130 \mathrm{~cm})$ in core T4. The assemblages of benthic foraminifera of these intervals are mainly constituted by species of the genus Ammonia (A. parkinsoniana, A. rolshaulseni and A. tepida), in addition to B. elegantissima, $C$. excavatum and E. gunteri.

According to Brönnimann et al. (1981), the species of the genus Ammonia, Cribroelphidium and Elphidium are dominant in the areas of greater instability of Sepetiba Bay. Several authors such as Zaninetti (1982,1984), Moodley and Hess (1992), Murray (1991, 2006), Alve and Murray (1999), Frontalini et al. (2009, 2013) also observed that Ammonia spp. and $C$. excavatum endure high concentrations of TOC and low oxygen levels. In addition, these species tolerate large salinity variations, conditions that prevail in the inner area of Sepetiba Bay. The highest densities of B. elegantissima between $\approx 3,000-2,000$ yrs cal BP may indicate greater oceanic influence in the area.

According to Murray (1991; 2006), B. elegantissima is a species that presents opportunistic behavior when the supply of organic matter increases and the oxygen concentrations drop, as observed by Vilela et al. (2014), Clemente et al. (2015) and Baptista-Neto et al. (2017), in Guanabara Bay (Brazil). According to Martins et al. (2016), B. elegantissima seems to prefer marine environments; it can live in transitional ecosystems in regions with good connection with marine waters. This trend was also observed by Eichler et al. (2003), in Guanabara Bay (Brazil), and Paquette et al. (2016) at Santa Catarina State coast (Brazil). In transitional settings, when the oceanic influence reduces, the abundance of this species declines and gives rise to other opportunistic species, such as Ammonia spp. and/or Cribroelphium/Elpbidium spp. (Martins et al., 2016).

In the middle section of the core $(240-130 \mathrm{~cm})$, events of more or less marked increase of foraminifera abundance were recorded. They occurred in coincidence with lower TOC content than in the upper core section (the first 130 $\mathrm{cm}$ ) but associated with low $\mathrm{C} / \mathrm{S}$ ratio values. The low $\mathrm{C} / \mathrm{S}$ values are indicative of low oxic conditions in sediments. The species present in this middle section are in general tolerant to oxygen scarcity. These results suggest that the oxygen depletion did not avoid the development of foraminifera communities. It can therefore be hypothesized that: the greatest oxygen scarcity in sediment pore-water should have happened in a post-depositional phase; or the organisms have benefited from the abundance of food, adopting an opportunistic behavior and living in oxic layers at the sediment-water interface. 


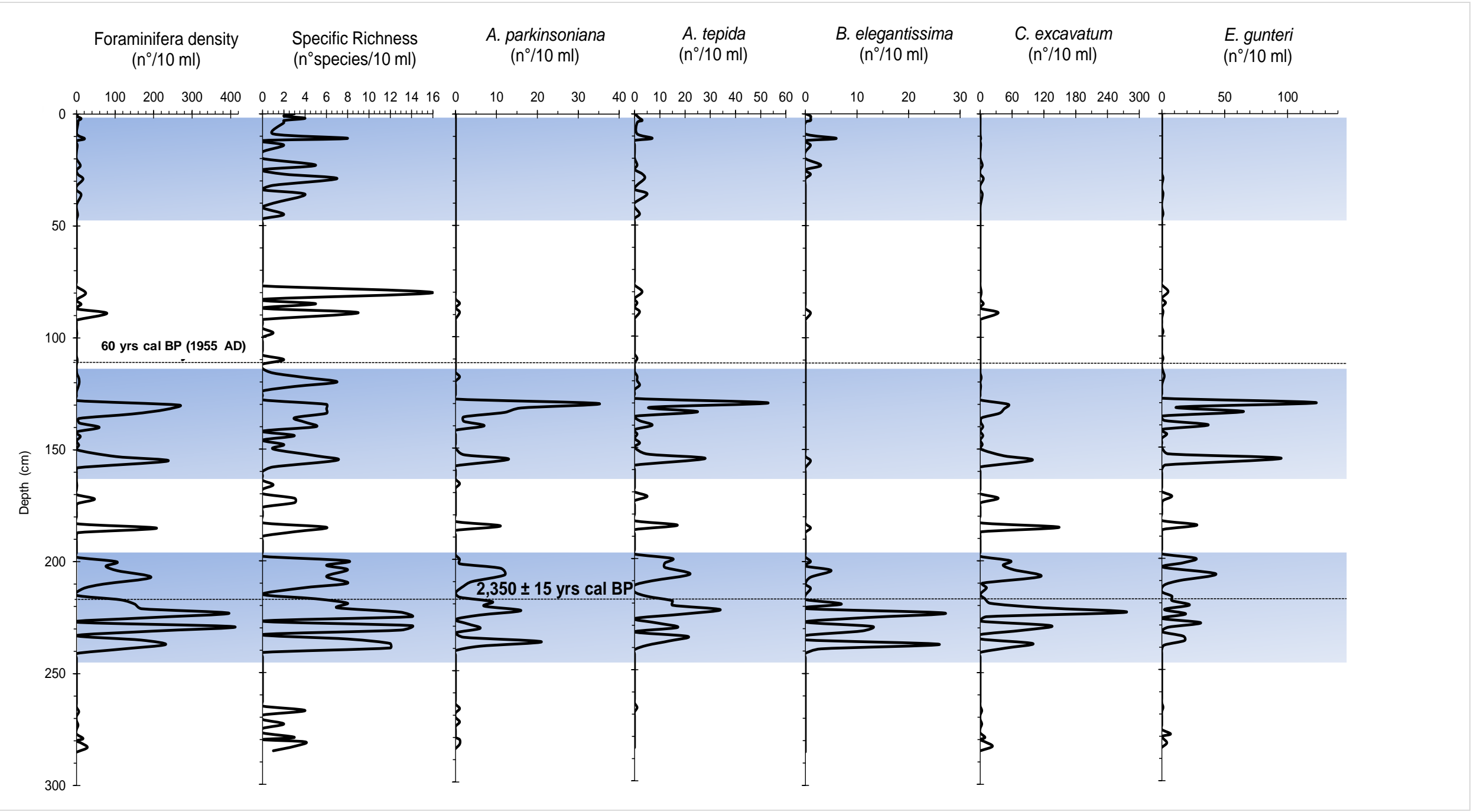

Fig. 4. Depth plot of foraminifera density ( $\mathrm{n}{ }^{\circ}$ of specimens $/ 10 \mathrm{ml}$ ), species richness (number of species $/ 10 \mathrm{ml}$ ) and the density of the most abundant species of foraminifera along the core T4. The blue bands indicate the sections with the highest densities and species richness, as well as the highest abundances ( . $^{\circ}$ of specimens $/ 10 \mathrm{ml}$ ) of the represented species. The obtained radiocarbon ages are also indicated. 
Tides are the main factor of renovation of the Sepetiba Bay waters (Cunha et al., 2006). According to Rodrigues (1990), the freshwater contributions correspond to $1.54 \%$ or $4.61 \%$ of the exchanges with the ocean if in syzygy or quadrature tide, respectively. The volumes exchanged predominantly by the tidal movements (since the fresh water contributions are not significant) allowed to estimate water renewal time of 3.28 days on average with 1.17 days in syzygy and 5.40 days in quadrature (Alves and Wasserman, 2002). Thus, at present, the water renovation in Sepetiba Bay is relatively rapid and the same is expected to have occurred in the Late Holocene.

Relatively high species richness in benthic foraminifera assemblages were recorded in the upper core section concomitant with a very low abundance of foraminifera. This issue may be related to the discharge of ballast water from ships (delivery of allochthonous material transported from other areas), a practice that has become quite common since the 1880s in coastal areas with maritime traffic (Carlton, 1985, 2001; Széchy et al., 2005). The release of ballast water and sediments in coastal areas is currently forbidden in Brazil, but it happened until recently, creating many types of problems (Zanella, 2010). This should explain the presence of species, of the genus Cibicides, for instance, common in in areas with active currents and shelf environments but is not in confined coastal environments (Murray, 2006; Martins et al., 2015; Yamashita et al., 2016).

\subsection{Changes in the last $\approx 4,000$ yrs BP}

Textural and microfaunal characteristics of core T4 collected in the inner region of Sepetiba Bay indicate that, in the last $\approx 4,000$ yrs cal BP, the study area was under the influence of periods of greater or lesser coastal hydrodynamics with oscillations in the water column depth. The exclusively calcareous fauna, with species adapted to variations of salinity and related to high nutrient and organic matter supply (also indicated by relatively high TOC contents; Fig. 6), similar to that found nowadays in Sepetiba Bay, shows that the study area has been a coastal environment similar to the current.

In the lower core section (Fig. 2), the occurrence of relatively coarse-grained sediments and the absence of foraminifera and high $\mathrm{CaCO}_{3}$ contents (Fig. 6) indicate that the study area should have been under dryness conditions, unfavorable to the development of foraminifera but propitious to the deposition of carbonates. Coarse sediments deposited in this period should be related to the incipient forced regression since 5,500-4,500 yrs BP, observed by Angulo et al. (2006), which caused a fast shoreline progradation (Abuchacra et al., 2017) or should be a late record of the Holocene transgression on the Pleistocene substrate evidenced by Friederichs et al. (2013) and Borges and Nittrouer (2015).

According to Pereira and Santos (2012) and Roncarati and Carelli (2012), Marambaia Barrier Island would have been largely developed at about $\approx 3,400$ yrs BP. The formation and evolution of the Marambaia Barrier are still a matter of debate (see, for instance, the work of Borges and Nittrouer, 2015). However, the results of our work also suggest that, since $\approx 3,400$ yrs BP, the inner area of Sepetiba Bay has become a protected system from the action of strong waves and active coastal currents. This area of Sepetiba Bay became a low energy system, which favored the deposition of fine-grained sediments.

Core T4 shows that the deposition of essentially fine sediments in this zone of the bay has occurred from $\approx 3,400$ yrs cal BP (Fig. 6). Since then, muddy sediments have been deposited in the study area, which suggests that the confinement originated by the development and evolution of the barrier beach was a determining factor for the accumulation of fine sediments in the inner zone of Sepetiba Bay.

The rainfall regime was another factor that may have contributed to this feature. According to Kirchner et al. (2015), the southeastern Brazilian region became increasingly humid between 4700-0.29 yrs cal BP. The rainfall increase caused river floods and probably increased the supply of fine-grained sediments to Sepetiba Bay. Sediments should have been accumulated in areas under low hydrodynamic conditions. Calm hydrodynamism and the abundant supply of sediments should have contributed to the accumulation of mud in the study area in the last $\approx 3,400$ yrs cal BP. Sediment accumulation rate should have been higher in the last $\approx 100$ years probably induced by anthropic interventions in the river basins (Kirchner et al., 2015).

In core $\mathrm{T} 1$, collected in the nearby Guaratiba Coastal Plain (mangrove), and analyzed by Pinto et al. (2016; Fig. 6) the period between $\approx 2,400-1,400$ yrs cal BP was signed by generic low abundance of foraminifera and carbonates content and slight increase of sand fraction. These authors suggested that, during this period, the area where the core T1 was collected, in Guaratiba Coastal Plain, should have been under the influence of the wavy action and shoreface sub-aerial processes. This period seems to be also recorded at least for the most part in core T4 and is marked by large variations of foraminifera abundance. Variations in the depth of the water column and hydrodynamic conditions in the region where core $\mathrm{T} 4$ was collected may have hindered 
the continued establishment of foraminifera associations. These observations allowed to deduce that between $\approx 2,400$ 1,400 yrs cal BP, the study area should have been under a shallow water column without favorable conditions for the chemical precipitation of carbonates probably due to a larger contribution of freshwater provided by the rivers to the inner region of Sepetiba Bay, which agrees with the observations of Kirchner et al. (2015).

During $\approx 1,400-300$ yrs cal BP, the area where the core T1 was collected, in Guaratiba Coastal Plain, undergone submergence (Pinto et al., 2016). In this period, the core T1 exhibited a fauna composed essentially of calcareous species, similar to that found in the core T4 (Fig. 6).

This kind of assemblage was found in core T4 in the section $(240-130 \mathrm{~cm})$ and is marked by events of significant increase of benthic foraminifera density (Fig. 6), which may also be associated with more favorable environmental conditions than that prevailed previously probably resultant of the deepening of the water column in this local.

In Guaratiba Coastal Plain the phase of greatest immersion may have occurred between $\approx 850-380$ yrs cal BP.
This period, recorded in core T1, is marked by the increase of benthic foraminifera density and species richness (Fig. 6). Ammonia tepida isotopic results obtained in core T1 suggest the occurrence of phases of increase or decrease of intake of cold and nutrient-rich marine waters in Guaratiba Coastal Plain (Pinto et al., 2016). Since the last $\approx 350$ yrs cal BP, the area where the core T1 was collected in Guaratiba Coastal Plain evolved to the current salt flat environment. On the other hand, the inner zone of Sepetibe Bay, where the core T4 was recovered, evolved for a each more confined and eutrophic environment.

The results obtained in the core T4 show that the eutrophication process of the internal zone of Sepetiba Bay began in the last $\approx 3,400 \mathrm{yrs}$ cal BP. The large increase of TOC occurred before the colonization of the region by the Portuguese colonizers (Vilela et al., 2014). So, the eutrophication process of the inner zone of Sepetiba Bay is being caused by other factors than human occupation such as geomorphological and climatic condition.

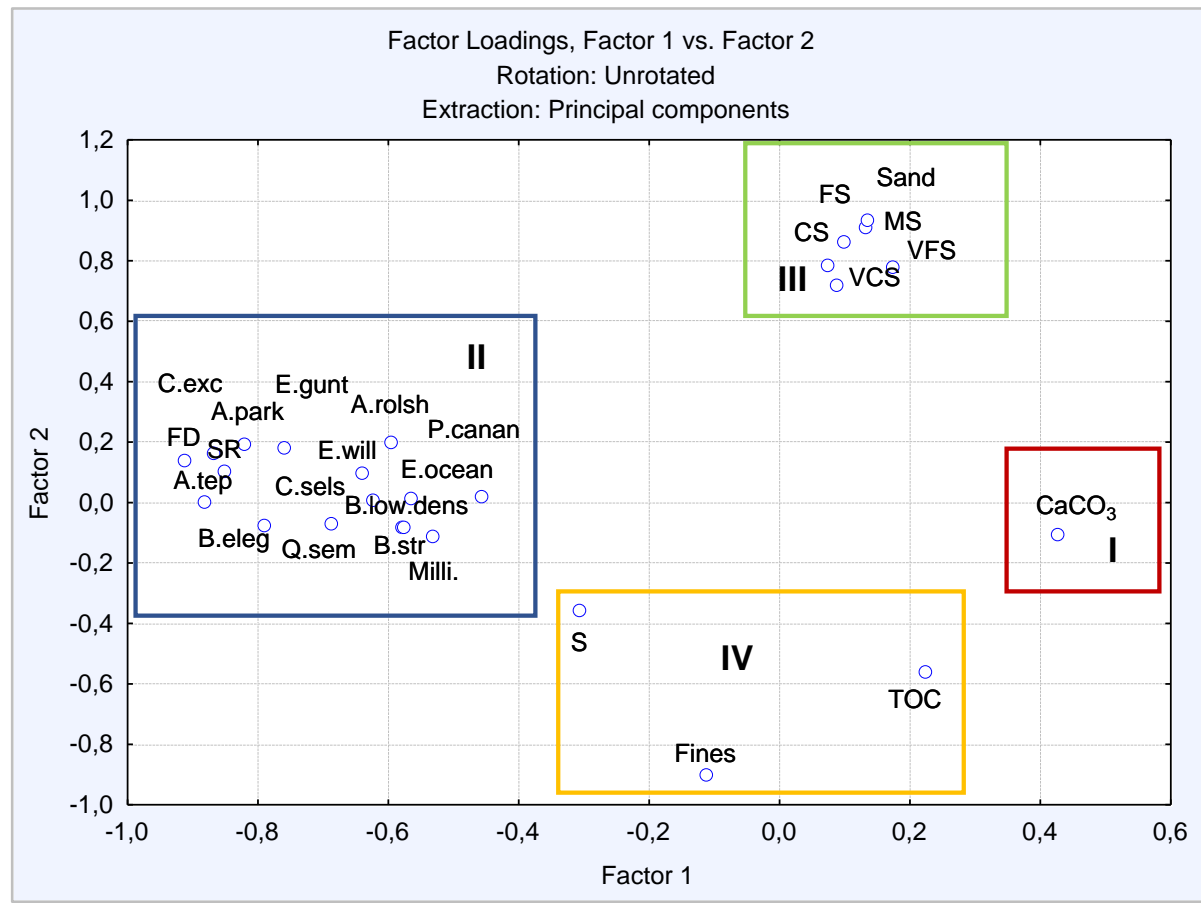

Fig. 5. Results of PCA based on the most significant variables (abundance of species and abiotic parameters). Legend: VCS - Very Coarse Sand ( $\%)$; CS - Coarse Sand ( $\%)$; MS - Medium Sand (\%); FS - Fine Sand (\%);VFS - Very Fine Sand (\%); Sand - Total Sand > 63 $\mu \mathrm{m}(\%)$; Fines - Total Fines $<63 \mu \mathrm{m}(\%)$; TOC - Total organic carbon $(\%)$; S - Total sulfur (\%); $\mathrm{CaCO}_{3}-\mathrm{CaCO}_{3}(\%)$; C/S - C/S ratio; FD Foraminifera Density ( ${ }^{\circ}$ specimens $/ 10 \mathrm{ml}$ ); SR - Species Richness ( $\mathrm{n}^{\circ}$ species $\left./ 10 \mathrm{ml}\right)$; and abundance of species $\left(\mathrm{n}^{\circ}\right.$ specimens $\left./ 10 \mathrm{ml}\right)$ of: A.park - Ammonia parkinsoniana; A.rolsh - Ammonia rolshauseni; A.tep - Ammonia tepida; B.low.dens - Bolivina lowmani densipunctata; B.str - Bolivina striatula; B.eleg - Buliminella elegantissima; C.exc - Cribroelphidium excavatum; C.sels - Cribroelphidium selseyense; E.gunt - Elphidium gunteri; E.ocean - Elphidium oceanense; E.will - Elphidium williamsoni; Milli.- Milliolids; P.canan - Pararotalia cananeiaensis; Q.sem - Quinqueloculina seminula. 


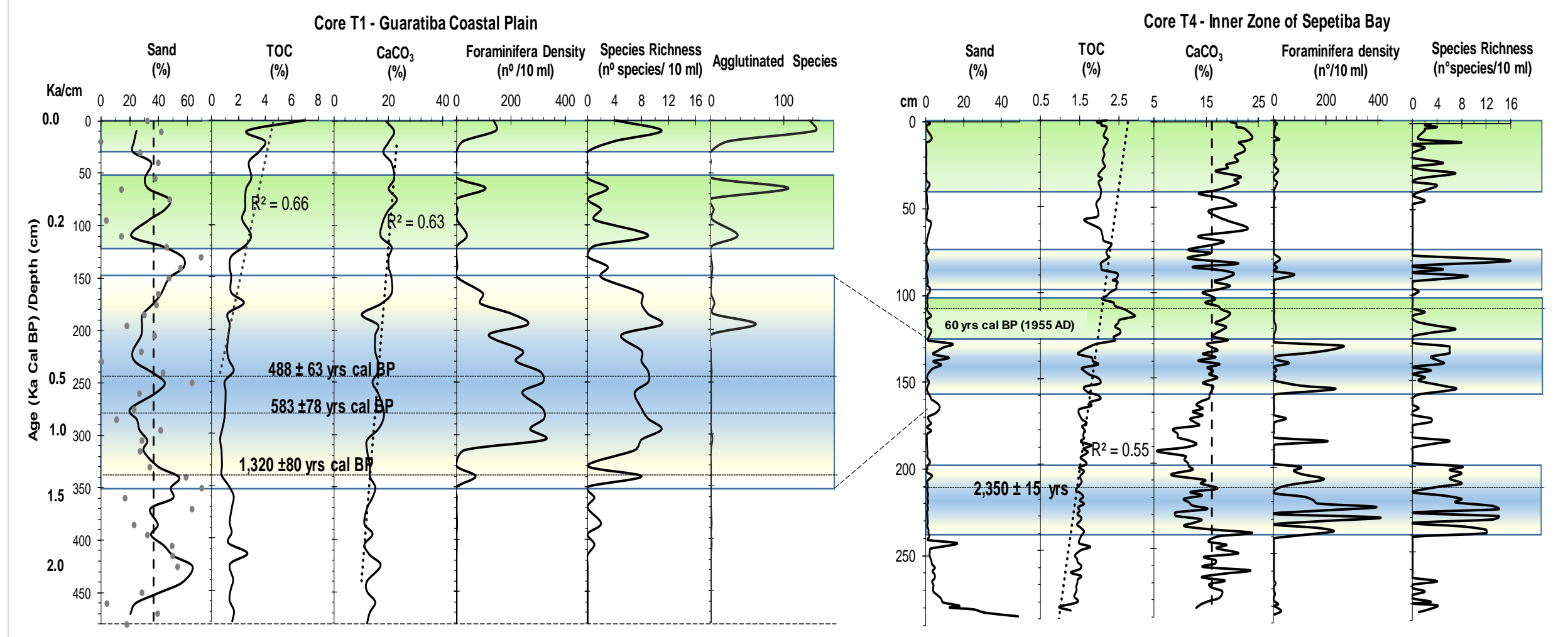

Fig. 6. Depth plot of the percentage of sand fraction (\%), TOC (\%), $\mathrm{CaCO}_{3}(\%)$, foraminifera density ( $\mathrm{n}^{\circ}$ specimens $/ 10 \mathrm{ml}$ ) and species richness (number of species/10 ml) along the cores T1 (analyzed by Pinto et al., 2016) and T4 (from this study). The abundance of the agglutinated species ( $\mathrm{n}^{\circ}$ specimens/10 ml) in the core T1 is also represented. The bands in blue color indicate sections with the highest foraminifera densities and species richness (in core T1, these bands point the presence of calcareous species); the bands in green color indicate the highest TOC and/or $\mathrm{CaCO}_{3}$ contents in both cores and the presence of agglutinated foraminifera in core T1. A scale of estimated ages (Ka - 1,000 years) for core T1 and the obtained radiocarbon ages are presented. The trend line and respective $\mathrm{R}^{2}$ value are displayed for the TOC depth plots in both cores, as well as for $\mathrm{CaCO}_{3}$ depth plot in core $\mathrm{T} 1$. 


\section{Conclusion}

The grain size and chemical composition of sediment core T4 indicate that the coarser layers should be related to periods of greater hydrodynamic conditions, less favorable to organic matter deposition and related to oxic sediments. The assemblages of benthic foraminifera composition found along this core are in accordance with a coastal environment that may have been under the influence of repeated events of increase and reduction of water column, in the last $\approx 4,000$ yrs BP.

During the last $\approx 3,400$ yrs cal $\mathrm{BP}$, a relatively calm scenario occurred in the inner zone of Sepetiba Bay. The evolution process of Marambaia Barrier Island probably contributed to the prevalence of low-energetic conditions in the internal region of Sepetiba Bay since $\approx 3,400 \mathrm{yrs}$ BP.

The filling of the inner zone of Sepetiba Bay with fine sediments enriched in organic matter began at about $\approx 3,400$ yrs cal BP. The greatest enrichment in organic matter was observed in the upper core section. Anthropogenic and natural factors should have contributed to the confinement and eutrophication of Sepetiba Bay since $\approx 3,400 \mathrm{yrs}$ cal BP.

\section{Acknowledgment}

This paper is a contribution of a project of Fundação Carlos Chagas Filho de Amparo à Pesquisa do Estado do Rio de Janeiro (FAPERJ; process \# APQ1 E26/111.398/2014). This work was partially supported by the project PEstOE/CTE/UI4035/2014, UID/GEO/04035/2013 of FCT, the Portuguese Science and Technology Foundation. The first author thanks the fellowship provided by Coordenação de Aperfeiçoamento de Pessoal de Nível Superior (CAPES). The authors also would like to thank Mr. Marcos Gonçalves of LGQM-UERJ and the team of the Laboratório de Oceanografia Geológica da Faculdade de OceanografiaUERJ.

Appendices 1-3 are attached as supplementary materials (SM1SM3) in http://www.epublicacoes.uerj.br/index.php/jse/article/view/28215

\section{References}

Abuchacra, R.C., Macario, K.C.D., Oliveira, M.I.N., Abuchacra, P.F.F., Fernandez, G.B., Vasconcelos, S.C., Oliveira, V.C., Ressiguier, Y.N., Figueiredo Jr., A.G., 2017. Northeast Guanabara Bay and coastal plain Holocene sedimentary evolution (Brazil): A contribution. Journal of Sedimentary Environments, 2 (1): 1-8.
RESEARCH PAPER

Alve, E., Murray, J.W., 1999. Marginal marine environments of the Skagerrak and Kattegat: a baseline study of living (stained) benthic foraminiferal ecology. Palaeogeography, Palaeoclimatology, Palaeoecology 146, 171-193. https://doi.org/10.1016/S0031-0182(98)00131-X

Alves, E., Macario, K., Souza, R., Pimenta, A., Douka, K., Oliveira, F., Chanca, I., Angulo, R., 2015. Radiocarbon reservoir corrections on the Brazilian coast from pre-bomb marine shells. Quaternary Geochronology 29, 30-35. https://doi.org/10.1016/j.quageo.2015.05.006

Alves, A.R., Wasserman, J.C., 2002. Determinação do tempo de renovação em sistemas lagunares. Mundo \& Vida: Alternativas em estudos Ambientais 3 (1), 48-53.

Angulo, R.J., Lessa, G.C., Souza, M.C. De, 2006. A critical review of mid- to late-Holocene sea-level fluctuations on the eastern Brazilian coastline. Quaternary Science Reviews 25, 486-506. https://doi.org/10.1016/j.quascirev.2005.03.008

Araújo, F.G., Santos, A.C.A., 1999. Distribution and recruitment of mojarras (Perciformes, Gerreidae) in the continental margin of Sepetiba Bay, Brazil. Bulletin of Marine Science 65(2), 431-439.

Baptista Neto, J.A., Barreto, C.F., Vilela, C.G., Fonseca, E.M, Melo, G.V., Ortrud, M.B., 2017. Environmental change in Guanabara Bay, SE Brazil, based in microfaunal, pollen and geochemical proxies in sedimentary cores. Ocean \& Coastal Management 143 (1), 4-15. https://doi.org/10.1016/j.ocecoaman.2016.04.010.

Belart, P., Laut, V.M, Clemente, I.M.M.M., Raposo, D.S., Martins, V., Frontalini, F., Lorini, M.L., Rafael Fortes, R.R., Laut, L.L.M., 2017. Living benthic Foraminifera from the Saquarema lagoonal system (Rio de Janeiro, southeastern Brazil). Check List 13(2), 2062. https://doi.org/10.15560/13.2.2062.

Borges, H.V., Nittrouer, C.A., 2016 a. Coastal Sedimentation in a Tropical Barrier-Island System During the Past Century in Sepetiba Bay, Brazil. Anuário do Instituto de Geociências UFRJ, 39 (2), 5-14.

Borges, H.V.; Nittrouer, C.A., 2016 b. Sediment accumulation in Sepetiba Bay (Brazil) during the Holocene: A reflex of the human influence. Journal of Sedimentary Environments 1(1), 96-112. https://doi.org/10.12957/jse.2016.21868

Borges, H.V., Nittrouer, C.A., 2015. The Paleo-Environmental Setting of Sepetiba Bay, Rio de Janeiro, Brazil, in the Late Pleistocene: Interpretations from High-Resolution Seismic Stratigraphy. Revista Brasileira de Geofisica 33. https://doi.org/10.22564/rbgf.vol33n4-2015

Borrego, J., Lopez, M., Pedon, J.G., Morales, J.A., 1998. C/S ratio in estuarine sediments of the Odiel River to mouth, S.W. Spain. Journal of Coastal Research 14, 1276-1283.

Brönnimann, P., Moura, J.A., Dias-Brito, D., 1981. Estudos Ecológicos na Baía de Sepetiba, Rio de Janeiro, Brasil: Foraminíferos. In: Anais do Congresso Latino-Americano de Paleontologia, Porto Alegre, RS, 862-875.

Bruno, M.R.L., 2013. Aplicabilidade dos foraminíferos bentônicos na restituição paleoambiental e no impacto antrópico da Laguna de Saquarema, Rio de Janeiro. Revista de Geologia 26 (1), 89-101. 
Calil, M., Soares-Gomes, A., Tavares, M., 2006. Spatial distribution of the major groups of Crustacea from infralitoral soft-bottoms at Sepetiba Bay. Journal of Coastal Research, SI 39, 1140-1143.

Carlton, J.T., 2001. Introduced species in U.S. coastal waters: environmental impacts and management priorities. Arlington, Pew Oceans Commission.

Carlton, J.T., 1985. Transoceanic and inter-oceanic dispersal of coastal marine organisms: the biology of ballast water. Oceanography and Marine Biology, Annual Review 23, 313-371.

Clemente, I.M.M.M., Silva, F.S., Laut, L.L.M., Frontalini, F., Costa, V.L., Rodrigues, M.A., Pereira, E., Bergamaschi, S., MendonçaFilho, J.G., Martins, M.V.A, 2015. Biochemical composition and foraminiferal content of sediments for determining bottom sector environments in Guanabara Bay (Rio de Janeiro, Brazil). Journal of Coastal Research 31(5), 1190-1204. https://doi.org/10.2112/JCOASTRES-D-14-00104.1

Copeland, G., Monteiro, T., Couch, S., Borthwick, A., 2003. Water quality in Sepetiba Bay, Brazil. Marine Environmental Research 55, 385-408.

Costa, K.B., Toledo, F.A.L., Pivel, M.A.G., Moura, C.A.V., Chemale Jr, F., 2006. Evaluation of two genera of benthic foraminifera for down-core paleotemperature studies in the Western South Atlantic. Brazilian Journal of Oceanography 54 (1), 75-84.

Cunha, C.L-N., Rosman, P.C.C., Ferreira, A.P., Monteiro, T.C.N, 2006. Hydrodynamics and water quality models applied to Sepetiba Bay. Continental Shelf Research 26 (16), 1940-1953. https://doi.org/10.1016/j.csr.2006.06.010

Debenay, J.-P., Bénéteau, E., Zhang, J., Stouff, V., Geslin, E., Redois, F., Fernandez-Gonzalez, M., 1998. Ammonia beccarii and Ammonia tepida (Foraminifera): morphofunctional arguments for their distinction. Marine Micropaleontology 34, 235-244.

DHN (Diretoria de Hidrografia e Navegação), 1986. Tábuas das marés para o ano de 1990 - costa do Brasil e portos estrangeiros. Marinha do Brasil, $255 \mathrm{pp}$.

Dornelles, L.M.A., 1998. Spatial distribution of heavy metals in the bottom sediments and suspended material: Sepetiba Bay, RJ, Brazil. Anais da Academia Brasileira de Ciências 70(2), 291-302.

Eichler, P.P.B., Eichler, B.B., Miranda, L.B., Pereira, E.R.M., Kfouri, P.B.P., Pimenta, F.M., Bérgamo A.L., Vilela, C.G., 2003. Benthic foraminiferal response to variations in temperature, salinity, dissolved oxygen and organic carbon, in the Guanabara Bay, Rio de Janeiro, Brazil. Anuário do Instituto de Geociências 26, 36-51.

Ferreira, A.P., Moreira, M.D.F.R., 2015. Metals pollution status in surface sediments along the Sepetiba Bay Watershed, Brazil. Journal Coast Zone Management, 18 (3), 1-5. https://doi.org/10.4172/2473-3350.1000404

Figueiredo Jr., A.G., Ivo, F.C., Guiro, P.P., Galea, C.G., Borges, H.V., Duque, H., 1989. Estratigrafia rasa da Baía de Sepetiba RJ. In: Anais do Congresso da Sociedade Brasileira de Geologia, I, Rio de Janeiro, p. 786-791.

Folk, R.L., Ward, W.C., 1957. Brazos River bar: a study in the significance of grain size parameters. Journal of Sedimentary Petrology 27, 3-26.
Fonseca, R.B.M., Abreu, K.C.C., Vilela, C.G., Baptista-Neto, J.A., 2007. Análise dos foraminíferos bentônicos de dois testemunhos na região nordeste da Baía de Guanabara. Anuário do Instituto de Geociências- UFRJ, 30 (1), 27-29.

Friederichs, Y.L., Reis, A.T., Silva, C.G., Toulemonde, B., Maia, R.M.C., Guerra, J.V., 2013. Arquitetura sísmica do sistema flúvio-estuarino da Baía de Sepetiba preservado na estratigrafia rasa da plataforma adjacente, Rio de Janeiro, Brasil. Brazilian Journal of Geology 43 (1), 124-138.

Frontalini, F, Margaritelli, G., Francescangeli, F., Rettor, R., Du Châtelet, E.A., 2013. Benthic foraminiferal assemblages and biotopes in a coastal lake: the case study of Lake Varano (Southern Italy). Acta Protozoologica 52(3), 147-1

Frontalini, F., Buosi, C., Da Pelo, S., Coccioni, R., Cherchi, A., Bucci, C., 2009. Benthic foraminifera as bio-indicators of heavy metal pollution in the heavily contaminated Santa Gilla lagoon (Cagliari, Italy). Marine Pollution Bulletin 58, 858-877.

Hayward, B.W., Cedhagen, T., Kaminski, M., Gross, O., 2017. World Foraminifera Database. Accessed at http:/ /www.marinespecies.org/foraminifera on 2017-03-10

International Joint Commission, 2001. Alien Invasive Species and Biological Pollution of the Great Lakes Basin Ecosystem. Report of the Great Lakes Water Quality Board to the IJC.

Kirchner, A., Nehren, U., Behling, H., Heinrich, J., 2015. Mid- and late Holocene fluvial dynamics in the tropical Guapi-Macacu catchment, Southeast Brazil: The role of climate change and human impact. Palaeogeography, Palaeoclimatology, Palaeoecology 426, 308-318. https://doi.org/10.1016/j.palaeo.2015.03.015

Kolar, C.S., Lodge, D.M., 2001. Progress in invasion biology: predicting invaders. Trends in Ecology and Evolution 16, 199204.

Lacerda, L.D., Marins, R.V., Paraquetti, H.H.M., Mounier, S., Benaim, J., Fevrier, D., 2001. Mercury distribution and reactivity in waters of a subtropical coastal lagoon, Sepetiba Bay, SE Brazil. Journal of the Brazilian Chemical Society 12(1), 93-98.

Lacerda, L.D., Pfeiffer, W.C., Fiszman, M., 1987. Heavy metal distribution, availability and fate in Sepetiba Bay, S.E. Brazil. The Science of the Total Environment, 65, 163-173.

Laut, L.M., Rodrigues, M.A.C., 2011. Foraminíferos do manguezal de Guaratiba, Rio de Janeiro: Revisão taxonômica e aplicação de análises multivariadas. In: Carvalho, I. et al. (Eds.), Paleontologia: Cenários da Vida. Rio de Janeiro, Interciência, 3, 231-240.

Laut, L.L.M., Koutsoukos, E.M.A., Rodrigues, M.A.C., 2006. Review of mangrove foraminifera from Guaratiba tidal plain, Rio de Janeiro, SE Brazil collected in the early 70's. Anuário do Instituto de Geociências- UFRJ, 29, 427-428.

Loeblich, A.R. Jr., Tappan, H., 1988. Foraminiferal Genera and Their Classification. New York: Van Nostrand Reinhold Company.

Martins, M.V.A., Soares-Gomes, A., Yamashita, C., Pinto, A.F.S., Frontalini, F., Sequeira, C., Laut, L.L.M., Belart, P., Zaaboub, N., Miranda, P., Sousa, S.H.M., Figueira, F., Pena, A.L., Terroso, D.L., Fernando Rocha, F., 2016. Similarity between 
the dead and living foraminiferal assemblages of the NE sector of Guanabara Bay (Brazil). Journal of Sedimentary Environments, 1(4), 419-439. https://doi.org/10.12957/jse.2016.26875

Martins, M.V.A., Quintino, V., Tentúgal, R.M., Frontalini, F., Miranda, P., Laut, L.L.M., Martins, R., Rodrigues, A.M., 2015. Characterization of bottom hydrodynamic conditions on the central western Portuguese continental shelf based on benthic foraminifera and sedimentary parameters. Marine Environmental Research 109, 52-68. https://doi.org/10.1016/j.marenvres.2015.06.006

Moodley, L., Hess, C., 1992.Tolerance of infaunal benthic foraminifera for low and high oxygen concentrations. The Biological Bulletin 183, 94-98.

Morse, J.W., Berner, R.A., 2000. What determines sedimentary C/S rations? Geochimica et Cosmochimica Acta 59, 10731077. https://doi.org/10.1016/0016-7037(95)00024-T

Murray, J.W., 2006. Ecology and Applications of Benthic Foraminifera. Cambridge, UK, Cambridge University Press, $426 \mathrm{p}$.

Murray, J.W., 1991. Ecology and Paleocology of Benthic Foraminifera. Longman Scientific \& Technical, Bath, 397 p.

Oliveira, L.M., Voltolini, J.C., Barbério, A., 2011. Potencial mutagênico dos poluentes da água do rio Paraíba do Sul em Tremembé, SP, Brasil, utilizando o teste Allium cepa. Revista Ambiente \& Água - An Interdisciplinary Journal of Applied Science 6 (1), 90-103. https://doi.org//10.4136/ambiagua.176

Paquette, M-L., Bonetti, C., Bitencourt, V., Bonetti, J., 2016. Spatial patterns of benthic foraminifera as a support to the oceanographic characterisation of Arvoredo biological marine reserve (South Atlantic, Brazil). Marine Environmental Research 114, 40-50.

Pereira, S.D., Santos, S.B., 2012. Restos de moluscos na Baía de Sepetiba como indicadores de alterações pretérias da linha de costa no Holoceno. In: Rodrigues, M.A.C., Pereira, S.D., Santos, S.B. (Eds.), Baia de Sepetiba Estado da Arte, Rio de Janeiro, Corbã, p. 105-111.

Petró, S.M., Pivel, M.A.G, Coimbra, J.C., Mizusaki, A.M.P., 2016. Paleoceanographic changes through the last $130 \mathrm{ka}$ in the Western South Atlantic based on planktonic foraminifera. Revista Brasileira de Paleontologia19 (1), 3-14.

Pinto, A.F.S., Martins, M.V.A., Rodrigues, M.A.C., Nogueira, L., Laut, L.L.M., Pereira, E., 2016. Late Holocene evolution of the Northeast intertidal region of Sepetiba Bay, Rio de Janeiro (Brazil). Journal of Sedimentary Environments 1(1), 113-144.

Raposo, D.S., Laut, V.M., Clemente, I.M.M.M., Martins, M.V.A. , Frontalini, F., Silva, F.S., Lorini, M.L., Fortes, R. R., Laut, L.L.M., 2016. Recent benthic foraminifera from the Itaipu Lagoon, Rio de Janeiro (southeastern Brazil). Check List 12 (5), 1-14. https://doi.org/10.15560/12.5.1959

Reimer, P.J., Bard, E., Bayliss, A., Beck, J.W., Blackwell, P.G., Ramsey, C.R., Buck, C., Cheng, H., Edwards, R.L., Friedrich, M., Grootes, P.M., Guilderson, T.P., Haflidason, H., Hajdas, I. Hatté, C., Heaton, T.J., Hoffmann, D.L., Hogg, A.G., Hughen, K.A., Kaiser, K.F., Kromer, B., Manning, S.W., Niu, M.,
RESEARCH PAPER

Reimer, R.W., Richards, D.A., Scott, E.M., Southon, J.R., Staff, R.A., Turney, C.S.M., van der Plicht, J., 2013. IntCal13 and Marine13 Radiocarbon Age Calibration Curves 0-50,000 Years cal BP. Radiocarbon 55, 1869-1887.

Rezende, C.E., Lacerda, L.D, Pfeiffer, W.C., 1991. Evolution of heavy metal contamination (1980-1989) of Sepetiba Bay determined using beach sand as monitors. Ciência e Cultura 43(1), 61-63.

Rodrigues, P.P.G.W., 1990. Aporte de metais pesados para a Baía de Sepetiba e seu comportamento na região estuarina. M.Sc Thesis in Geosciences, Department of Geochemistry, Universidade Federal Fluminense, Niterói, 161 p.

Roncarati, H., Carelli, S.G., 2012. Considerações sobre o estado da arte dos processos geológicos cenozóicos atuantes na Baía de Sepetiba. In: Rodrigues, M.A.C, Pereira, S.D, Santos, S.B. (Eds.). Baía de Sepetiba: Estado da Arte, Rio de Janeiro, Corbã, p. 13-36.

Rouchy, J.M., Taberner, C., Peryt, T.M., 2001. Sedimentary and diagenetic transitions between carbonates and evaporites. Sedimentary Geology 140, 1-8.

Schönfeld, J., Alve, E., Geslin, E., Jorissen, F., Korsun, S., Spezzaferri, S. and members of the FOBIMO group, 2012. The FOBIMO (FOraminiferal BIo-MOnitoring) initiative Towards a standardised protocol for soft-bottom benthic foraminiferal monitoring studies. Marine Micropaleontology 94-95, 1-13.

Semensatto-Jr, D.L., Dias-Brito, D., 2004. Análise Ambiental de uma área parálica no delta do Rio São Francisco, Sergipe-Brasil, com base na sinecologia de foraminíferos e tecamebas (Protista). Revista Brasileira de Paleontologia 7, 53-66.

Stein, R., 1991. Accumulation of organic carbon in marine sediments. Results from the Deep Sea Drilling Project/Ocean Drilling Program. In: Bhattacharji, S., Friedman, G.M., Neugebauer, H. J., Seilacher (Eds.), A. Lecture Notes in Earth Sciences, Berlin, Springer, $217 \mathrm{p}$

Suguio, K., Vieira, E.M., Barcelos, J.H., Silva, M.S., 1979. Interpretação ecológica dos foraminíferos de sedimentos modernos da Baía de Sepetiba e adjacências, Rio de Janeiro. Revista Brasileira de Geociências 9 (4), 233-247.

Széchy, M.T.M., Amado Filho, G.M., Cassano, V., De-Paula, J.C., Barreto, M.B.B., Reis, R.P., Marins-Rosa, B.V., Moreira, F.M., 2005. Levantamento florístico das macroalgas da Baía de Sepetiba e adjacências, RJ: ponto de partida para o Programa GloBallast no Brasil. Acta Botanica Brasilica19 (3), 587-596.

Tenenbaum, D. R., Villac, M. C., Viana, S. C., Matos, M., Hatherly, M., Lima, I.V., Menezes, M., 2004. Phytoplankton identification atlas Sepetiba Bay, Brazil. Rio de Janeiro/London, IOC, $100 \mathrm{p}$.

Tubbs Filho, D., Antunes, J.C.O., Vettorazzi, J.S. (Org.), 2012. Bacia Hidrográfica dos Rios Guandú, da Guarda e GuandúMirim. Experiências para a gestão dos recursos hídricos. Rio de Janeiro. Instituto Estadual do Ambiente (Inea).

Uehara, R.S., Duleba, W., Petri, S., Mahiques, M.M., Rodrigues, M., 2007. Micropaleontologia e Sedimentologia Aplicadas à Análise Paleoambiental: um Estudo de Caso em Cananéia, São Paulo, Brasil. Revista Brasileira de Paleontologia 10, 137-150. 
Vilela, C.G., Figueira, B.O., Cardoso Macedo, M.C., Baptista Neto, J.A., 2014. Late Holocene evolution and increasing pollution in Guanabara Bay, Rio de Janeiro, SE Brazil. Marine Pollution Bulletin 79 (1-2), 175-187.

Villena, H.H., Pereira, S.D., Chaves, H.A.F., Dias, M.S., Guerra, J.V., 2012. Indícios da Variação do Nível do Mar na Baía de Sepetiba. In: Rodrigues, M.A.C., Pereira, S.D., Santos, S.B. (Eds.). Baía de Sepetiba: Estado da Arte. Rio de Janeiro, Corbã, p. 39-82.

Yamashita, C., Nagai, R.N., Martins, M.V.A., Vicente, T.M., Sousa, S.H.M., Frontalini, F., Palóczy, A., Mahiques, M.M., Godoi, S.S., Montoya-Montes, I., Figueira, R.C.L., 2016. On the interplay between hydrodynamics, bottom morphology, sedimentary processes and benthic foraminifera assemblages in
RESEARCH PAPER

the São Paulo Bight (Brazil, SW Atlantic). Journal of Sedimentary Environments 1(3), 334-355. https://doi.org/10.12957/jse.2016.25990

Zanella, T.V., 2010. Água de Lastro: um problema ambiental global. Curitiba; Juruá.

Zaninetti, L., 1984. Les foraminifers du salin de Bras del Port (Santa Pola, Espagne) avec remarques sur le distribution des ostracodes. Revista d'investigacions geologiques 38/39, 123 138.

Zaninetti, L., 1982. Les foraminifères des marais salants de Salinde-Giraud (sud de la France): milieu de vie et transports dans le salin, comparaison avec les microfaunes marines. Geólogie Méditerranéene 9, 447-70 